\title{
Dwindling Electrical Power Supply in Nigeria: Causes and Possible Solutions
}

\author{
S. D. Fabiyi ${ }^{1}$, A. O. Abdulmalik ${ }^{2}$, H. A. Tiamiu ${ }^{3}$ \\ ${ }^{1}$ Department of Mechatronics Engineering, Federal University of Technology, \\ Gidan Kwano, Bosso Local Government Area, Minna, Nigeria \\ ${ }^{2}$ Department of Mechatronics Engineering, Federal University of Technology, \\ Gidan Kwano, Bosso Local Government Area, Minna, Nigeria \\ ${ }^{3}$ Halex Auto-solution, Owobi Ota, Ogun State
}

\begin{abstract}
The effects of power outage on businesses can be catastrophic. Enjoyment of basic social amenities such as quality health care, adequate water supply, telecommunication service, etc becomes limited or even impossible due to long term electrical power outage. Huge revenue loss, business disruptions, laying-off of workers by affected industries, loss of very important records at data centers, wastage of perishable foods, destruction of home appliances, etc are some of the effects of dwindling electrical power supply. This paper seeks to find out the root causes of electrical power crisis in Nigeria and to put possible solutions forward. Data was acquired by administering questionnaires in all the local government areas of Minna, Niger State with focus on people in the mostly affected areas and experts in the field. For analysis of the data collected through the use of selected research tool, a method of simple percentage was adopted. In other to present identified causes of electrical power crises in Nigeria according to their level of responsibility, responses are coded by assigning value to each scale and so the method of sum was also adopted. The results showed that the rate of electricity supply in Nigeria is in the low state. Continued use of aged equipment, Poor maintenance culture, Corruption, and looting of fund meant for power sector reform have been identified as the major causes of dwindling electrical power supply in Nigeria.
\end{abstract}

Keywords: Nigeria, electricity, availability, dwindling, power supply

\section{Introduction}

It is not an overstatement to say that electricity supply contributed largely in making the world what it is today. Its importance to the masses, industries, etc cannot be overemphasized. The use of electric irons, televisions, radios, washing machines, refrigerators, video players, cookers, computers, fans, air-conditioners, etc are all made possible through electricity supply. In other words, any nation without electricity supply is like a car without fuel, she will remain stagnant.

The issue of epileptic power supply in Nigeria has been a major concern, not just to the citizens, but also to the federal government and the companies under various industries. With the intention of addressing the issue of electrical power crisis and improving the reliability of the electrical power system, the federal government have, at one time or the order, had to: merge Electricity Corporation of Nigeria (ECN) and Niger Delta Authority (NDA) to National Electric Power Authority (NEPA) in 1972; change NEPA's nomenclature to Power Holding Company of Nigeria (PHCN) in 2005, focusing mainly on restructuring; privatize and split $\mathrm{PHCH}$ into 18 companies in 2012. However, records obtained so far have shown that all of these have had little or no positive impact on availability of electricity which is of utmost concern to consumers $[4,5]$.

Early this year (2016), power generation reportedly dropped from 5000 megawatts to below 1600 megawatts. This worsened state of electrical power supply generated lots of wave and outcry among electricity consumers especially on the social websites. In other to save us this unnecessary national embarrassment and to bring the vision 20-2020 in to a reality i.e. to be among the top twenty industrialized country by the year 2020 , the problem of dwindling electrical power supply must be tackled head-on [8].

Epileptic power supply in Nigeria has been a major barrier to the growth of our economy. The effects of power outage on businesses can be catastrophic. Enjoyment of basic social amenities such as quality health care, adequate water supply, telecommunication service, etc becomes limited or even impossible due to long term electrical power outage. Huge revenue loss, business disruptions, laying-off of workers by affected industries, loss of very important records at data centers, wastage of perishable foods, destruction of home appliances, etc are some of the effects of electrical power crisis. All the mechanisms put in place by present and past governments to checkmate this anomaly seems not to be working. There is a need for a robust method to be adopted to identify the root causes. Several papers have been written and published on related issues.

A. Oluwole, O. Samuel, O. Festus and O. Olatunji. (2012), in their paper titled, "Electrical Power Outage In Nigeria: History, Causes and Possible Solutions." pinpointed low water levels, unavailability of gas to power the turbines and inadequate plant maintenance as the major causes of discrepancies between electricity demand and actual power generation [3].

A. A. Ponnle (June, 2005), in his paper titled, "Performance of Domestic AC Voltage Stabilizers in Meeting Low Voltage Problems in Nigeria: A Case Study of 12 Different Brands" attributed the long hours of blackout always experienced in 


\section{International Journal of Science and Research (IJSR) \\ ISSN (Online): 2319-7064 \\ Index Copernicus Value (2013): 6.14 | Impact Factor (2015): 6.391}

some areas to the shedding of load by electricity distribution companies. According to him, electricity distribution companies always resort to load shedding due to the small amount of power being generated in the country [1].

A. C. Ohajianya, O. E. Abumere, I. O. Owate, and E. Osarolube (July 2014), in their paper, identified incompetence of staff of the energy companies, inconsistent energy policies of the federal government and inefficient power generation, transmission, distribution and consumption as the major factors responsible for erratic power supply in Nigeria [2].

C. A. Awosope (October, 2014), in his public lecture on Nigeria Electricity industry; Issues, challenges and solutions, identified lack of good maintenance culture as the reason behind investors' unwillingness to patronize the Nigerian electricity supply industry (NESI). He also listed lack of modern equipment, lack of policy that support the local production of machines and spare parts, and low morale among workers and embargo on employment as some of the effects of insufficient funding on power availability [5].

The objectives of this research work are to obtain relevant data and to carry out analysis of this data with the aim of finding out the root causes of electrical power crisis in Nigeria and to put possible solutions forward.

\section{Methodology}

The proposed methodology adopted for this work is presented using a flowchart shown in figure 1. The material and analytical tool used for this work are questionnaire and Surveypro 5 respectively. In other to get sufficient information that will enable us to get to the root of the problem of dwindling electrical power supply in Nigeria and to identify the major causes, a survey method through the use of questionnaire was adopted. Data was acquired by administering questionnaires in all the local government areas of Minna, Niger State with focus on people in the mostly affected areas and experts in the field.

The questionnaire was painstakingly designed in such a way that the data collected could be easily analyzed. An extensive analysis of the data collected was then carried out. The graphical representation of the sequence of operations carried out to achieve the objectives of this work is shown in figure 1. For analysis of the data collected through the use of selected research tool, a method of simple percentage was adopted. For every question raised in the questionnaire, percentage was calculated by dividing the total number of respondents by the observed frequency and the result multiplied by 100 .

$$
\%=\frac{F}{N} * 100
$$

Where $\%=$ percentage

$\mathrm{F}=$ Frequency

$\mathrm{N}=$ Number of respondents
For analysis of the data obtained through the use likert scales and presentation of identified causes of electrical power crises in Nigeria according to their level of responsibility, responses were coded by assigning value to each scale and the method of sum adopted.

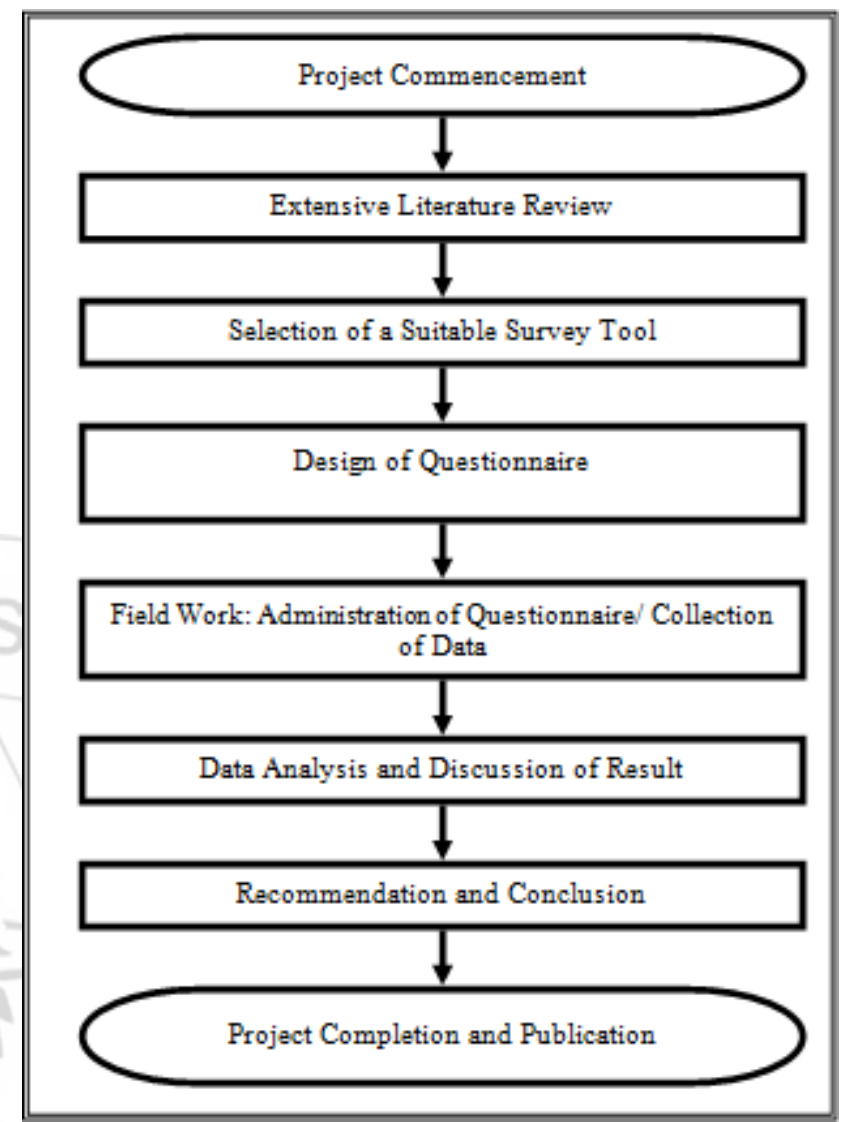

Figure 1: Graphical representation of the sequence of operations

The method of Chi-square was initially considered for data analysis but was later discarded because there were no expected answers to be compared with the actual responses from the respondents. Hence, the methods of simple percentage and sum were adopted. Relevant literatures have been reviewed in section 1. Data collection and analysis have been discussed earlier in this section. The rest of the paper is organized as follows: results and discussion are presented in sections 3 and 4 respectively. Section 5 and 6 presents the possible solutions and conclusion respectively.

\section{Results}

Table 1: Are you satisfied with the current state of Electricity in your area?

\begin{tabular}{|c|c|c|c|}
\hline$S / N$ & & Counts & Percents (\%) \\
\hline 1 & Yes & 54 & 22.50 \\
\hline 2 & Uncertain & 30 & 12.50 \\
\hline 2 & No & 156 & 65.50 \\
\hline & TOTAL & 240 & 100 \\
\hline
\end{tabular}




\section{International Journal of Science and Research (IJSR) \\ ISSN (Online): 2319-7064}

Index Copernicus Value (2013): 6.14 | Impact Factor (2015): 6.391

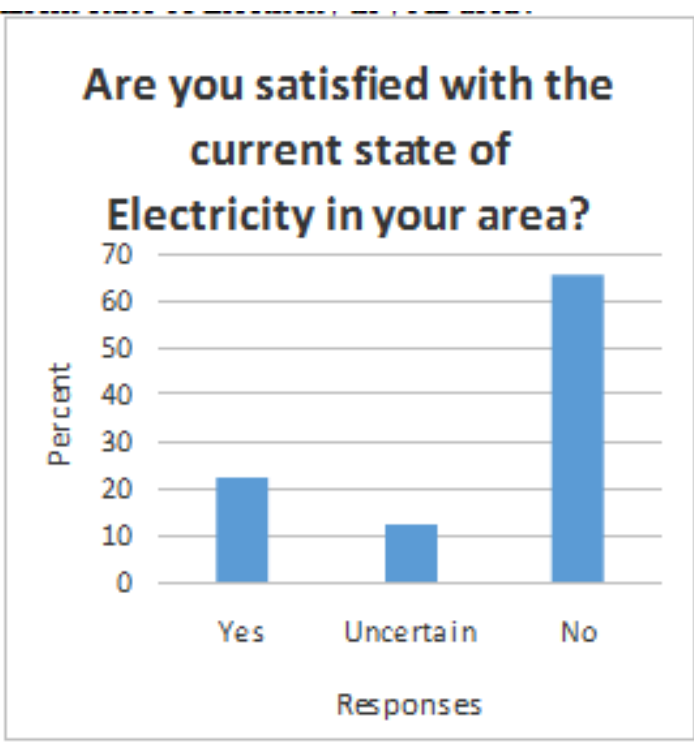

Figure 2: Are you satisfied with the current state of Electricity in your area?

Table 2: Rate the supply of Electricity in your area

\begin{tabular}{|c|c|c|c|}
\hline$S / N$ & & Counts & Percents (\%) \\
\hline 1 & High & 24 & 10 \\
\hline 2 & Manageable & 72 & 30 \\
\hline 3 & Low & 144 & 60 \\
\hline & TOTAL & 240 & 100 \\
\hline
\end{tabular}



Figure 3: Rate the supply of Electricity in your area

Table 3: Privatization has been able to solve the problem of dwindling Electricity supply in Nigeria

\begin{tabular}{|c|c|c|c|}
\hline$S / N$ & & Counts & Percent $(\%)$ \\
\hline 1 & Agree & 57 & 23.75 \\
\hline 2 & Disagree & 183 & 76.25 \\
\hline & TOTAL & 240 & 100 \\
\hline
\end{tabular}

Privatisation has been able to solve the problem of dwindling

Electricity supply in Nigeria

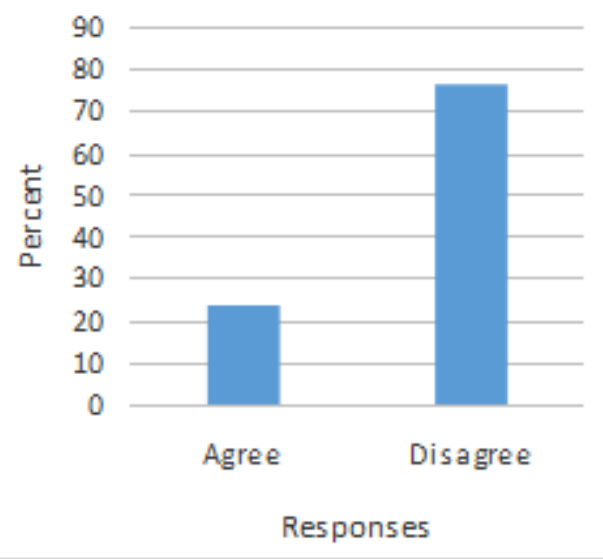

Figure 4: Privatization has been able to solve the problem of dwindling Electricity supply in Nigeria

Table 4: Which of the following are responsible for the dwindling electricity supply in Nigeria where Un stands for

\begin{tabular}{|c|c|c|c|c|}
\hline$S / N$ & Likely causes & Yes & No & $U n$ \\
\hline 1 & $\begin{array}{l}\text { Corruption and looting of fund meant } \\
\text { for power sector reform }\end{array}$ & $\begin{array}{c}180 \\
/ \\
75.9 \\
\% \\
\end{array}$ & $\begin{array}{c}51 / \\
21.5 \\
\%\end{array}$ & $\begin{array}{c}6 \\
2.5 \\
\%\end{array}$ \\
\hline 2 & $\begin{array}{l}\text { Over-dependence on Hydro-Electric } \\
\text { Power }\end{array}$ & $\begin{array}{c}168 \\
/ \\
70.9 \\
\%\end{array}$ & $\begin{array}{c}21 / \\
8.9 \\
\%\end{array}$ & $\begin{array}{c}48 / \\
20 . \\
3 \\
\%\end{array}$ \\
\hline 3 & Load shedding & $\begin{array}{c}69 / \\
33.8 \\
\%\end{array}$ & $\begin{array}{c}81 / \\
39.7 \\
\%\end{array}$ & $\begin{array}{c}54 \\
26 . \\
5 \\
\%\end{array}$ \\
\hline 4 & $\begin{array}{l}\text { Incompetence of staff of energy } \\
\text { companies }\end{array}$ & $\begin{array}{c}108 \\
/ \\
46.2 \\
\%\end{array}$ & $\begin{array}{c}60 / \\
25.6 \\
\%\end{array}$ & $\begin{array}{c}66 \\
28 . \\
2 \\
\%\end{array}$ \\
\hline 5 & Continued use of aged equipment & $\begin{array}{c}186 \\
/ \\
79.5 \\
\%\end{array}$ & $\begin{array}{c}33 / \\
14.1 \\
\%\end{array}$ & $\begin{array}{l}15 / \\
6.4 \\
\%\end{array}$ \\
\hline 6 & Poor maintenance culture & $\begin{array}{c}165 \\
/ \\
78.6 \\
\%\end{array}$ & $\begin{array}{c}18 / \\
8.6 \\
\%\end{array}$ & $\begin{array}{c}27 / \\
12 . \\
9 \\
\%\end{array}$ \\
\hline 7 & Drought, wind, lightning, flood, etc. & $\begin{array}{c}84 / \\
35.9 \\
\%\end{array}$ & $\begin{array}{c}51 / \\
21.8 \\
\%\end{array}$ & $\begin{array}{c}99 / \\
42 . \\
3 \\
\%\end{array}$ \\
\hline 8 & $\begin{array}{l}\text { Inconsistent energy policies of the } \\
\text { federal government }\end{array}$ & $\begin{array}{c}147 \\
/ \\
61.3 \\
\%\end{array}$ & $\begin{array}{c}78 / \\
32.5 \\
\%\end{array}$ & $\begin{array}{c}15 / \\
6.2 \\
5 \\
\%\end{array}$ \\
\hline 9 & $\begin{array}{l}\text { Theft and vandalisation of electrical } \\
\text { power equipment }\end{array}$ & $\begin{array}{c}168 \\
/ \\
70.9 \\
\%\end{array}$ & $\begin{array}{c}51 / \\
21.5 \\
\%\end{array}$ & $\begin{array}{c}18 / \\
7.6 \\
\%\end{array}$ \\
\hline
\end{tabular}




\section{International Journal of Science and Research (IJSR) \\ ISSN (Online): 2319-7064 \\ Index Copernicus Value (2013): 6.14 | Impact Factor (2015): 6.391}

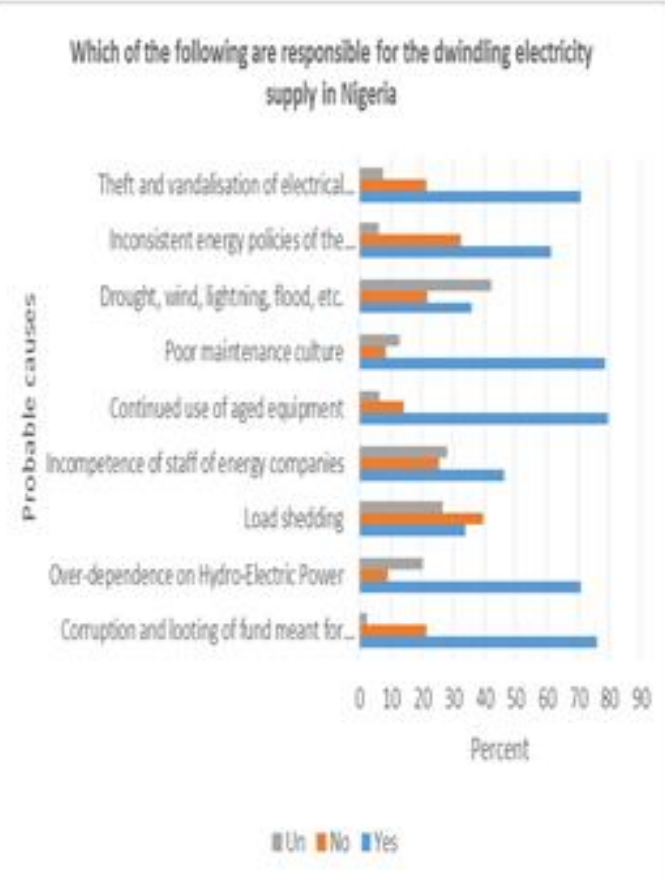

Figure 5: Which of the following are responsible for the dwindling electricity supply in Nigeria where Un stands for uncertain (count/percent)

Table 5: Rating the level of responsibility of each of the identified causes

\begin{tabular}{|c|c|c|c|}
\hline$S / N$ & Likely causes & Sum & Percents (\%) \\
\hline 1 & $\begin{array}{l}\text { Corruption and looting of } \\
\text { fund meant for power sector } \\
\text { reform }\end{array}$ & 759 & 13.12 \\
\hline 2 & $\begin{array}{l}\text { Over-dependence on Hydro- } \\
\text { Electric Power }\end{array}$ & 747 & 12.91 \\
\hline 3 & Load shedding & 429 & 7.41 \\
\hline 4 & $\begin{array}{l}\text { Incompetence of staff of } \\
\text { energy companies }\end{array}$ & 537 & 9.28 \\
\hline 5 & $\begin{array}{l}\text { Continued use of aged } \\
\text { equipment }\end{array}$ & 795 & 13.74 \\
\hline 6 & Poor maintenance culture & 768 & 13.27 \\
\hline 7 & $\begin{array}{l}\text { Drought, wind, lightning, } \\
\text { flood, etc. }\end{array}$ & 384 & \\
\hline 8 & $\begin{array}{l}\text { Inconsistent energy policies } \\
\text { of the federal government }\end{array}$ & 6 & 11.20 \\
\hline 9 & $\begin{array}{l}\text { Theft and vandalisation of } \\
\text { electrical power equipment }\end{array}$ & 720 & 12.44 \\
\hline
\end{tabular}

\section{Discussion}

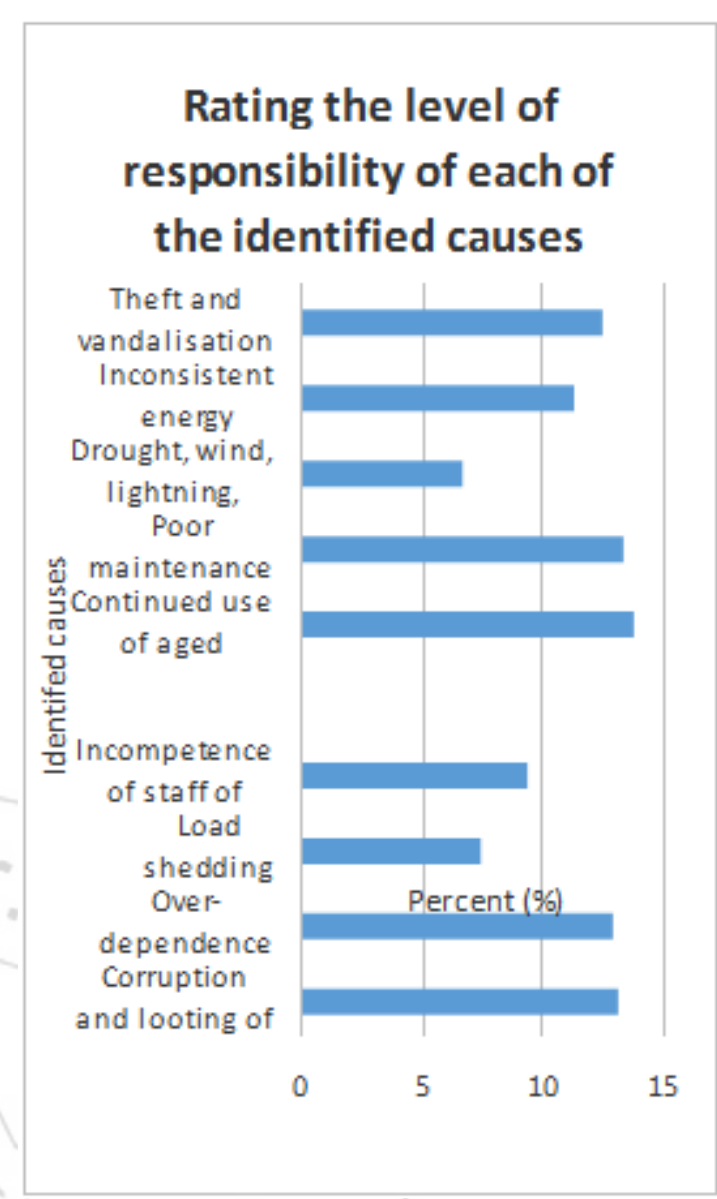

Figure 6: Rating the level of responsibility of each of the

65.5 percent of respondents were not satisfied with the current state of electricity in the country, 60 percents of respondents claimed the rate of electricity supply in their respective areas is in the low state while 76.25 percents of respondents believed privatization has not been able to solve the problem of dwindling electrical power crises in Nigeria. Continued use of aged equipment, Poor maintenance culture, Corruption, and looting of fund meant for power sector reform have been identified as the major causes of dwindling electrical power supply in Nigeria. Identified as not too far from the major causes are: Over-dependence on HydroElectric Power, Theft and vandalisation of electrical power equipment, Inconsistent energy policies of the federal government while the minor causes. include: Incompetence of staff of energy companies, Load shedding, and Drought, wind, lightning, flood, etc.

\section{Possible Solutions}

The measures listed below have been selected based on the opinion/information gathered from respondents and if taken, will go a long way in solving the problem of dwindling electrical power supply in Nigeria:

- Replacement of aged equipment with new ones (tested and of high quality). 


\section{International Journal of Science and Research (IJSR) \\ ISSN (Online): 2319-7064}

Index Copernicus Value (2013): 6.14 | Impact Factor (2015): 6.391

- Proper and adequate maintenance of electrical power equipment.

- Stringent and urgent action should be taken by anticorruption agencies to nip the problem of corruption and looting of funds meant for power sector reform in the bud.

- Other means of power generation should be explored e.g. solar and nuclear power plants.

- Staff of energy companies should be trained and re-trained.

- Prompt payment of salary and entitlement of staff of energy companies.

- Government should come up with policies and support systems for effective monitoring and regulation of energy companies.

- Government should follow-up on energy policies formulated.

- Provision of adequate transformers to localities where such are needed to avoid overloading.

\section{Conclusion}

The results showed that the current rate of electricity supply in the country is in the low state with 65.5 percents of respondents claiming they were not satisfied with the rate of supply in their respective areas. Continued use of aged equipment, poor maintenance culture, corruption, and looting of fund meant for power sector reform have been identified as the major causes of dwindling electrical power supply in Nigeria. Hence, possible solutions were put forward some of which are: Replacement of aged equipment with new ones (tested and of high quality); Proper and adequate maintenance of electrical power equipment; Stringent and urgent action should taken by anti-corruption agencies to nip the problem of corruption and looting of funds meant for power sector reform in the bud. If the outcome of this work is made available to the government, relevant agencies, energy companies, etc. It will, in no doubt, help to solve the problem of dwindling electrical power supply in Nigeria permanently.

\section{References}

[1] A. A. Ponnle. (2015, June). "Performance of Domestic AC Voltage Stabilizers in Meeting Low Voltage Problems in Nigeria: A Case Study of 12 Different Brands." International Journal of Engineering and Technology, [On-line]. 5(6), pp. 358-367. Available: www.iet-

journals.org/archive/2015/june_vol_5_no_6/6589414298 8837_abstract.php [Feb. 5, 2016]. (journal style)

[2] A. C. Ohajianya, O. E. Abumere, I. O. Owate and E. Osarolube. (2014, July)."Erratic Power Supply in Nigeria: Causes and Solutions." International Journal of Engineering Science Invention. [On-line]. 3(7), pp. 5155.

Available:

http://www.ijesi.org/papers/Vol\%283\%297/Version1/G0371051055.pdf [Feb. 5, 2016]. (journal style)

[3] A. Oluwole, O. Samuel, O. Festus and O. Olatunji. (2012). "Electrical Power Outage in Nigeria: History, Causes and Possible Solutions." Journal of Energy Technologies and Policies. [On-line]. 2(6), pp. 18-23. Available:http://www.iiste.org/Journals/index.php/JETP/
article/viewFile/2566/2582 [Feb. 19, 2016]. (Journal style)

[4] A. W. Ojiezel. "FG Splits PHCN In To 18 Successor Companies." Internet: www.nationaldailyng.com/business/labour, Dec. 18, 2012 [Feb. 18, 2016]. (General Internet site)

[5] C. A. Awosope, $38^{\text {th }}$ public lecture, Topic:" Nigeria Electricity Industry: Issues, Challenges and Solutions." Covenant University, Ota, Ogun State, Nigeria, Oct. 2014. (General Internet site)

[6] D. Laary. "Electricity: Ghana Power Crisis deepens," The African Report. Internet:www.theafricanreport.com/electricity-ghanaspower-crisis, Feb. 4, 2015 [Feb. 19, 2016]. (General Internet site)

[7] "Energy Risks - The Dangers of Power Cuts and Blackouts." www.agcs.allianz.com/insights/expert-riskarticles/energy-risks, [Feb. 8, 2016]. (General Internet site)

[8] S. Opejobi. "Fashola under Fire over Worsening State of Electricity." Internet: www.dailypost.ng/2016/03/10/fashola-under-fire-overworsening-state-of-electricity, Mar. 3, 2016 [Mar. 13, 2016]. (General Internet site)

[9] “Top Ten Industries That Would Be Affected Most By A Power Outage." Internet: www.dieselserviceandsupply.com/industry_power_outag es.aspx, [Feb. 8, 2016] (General Internet site)

\section{Author Profile}

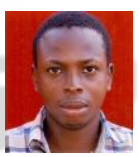

Samson Damilola FABIYI received B. Eng Electrical and Electronics Engineering (with first class and CGPA of 4.72) from University of Ilorin, Nigeria in 2015. He scored a GPA of 5.0 in the first and second semesters, 2014/2015 academic session. He also received National Diploma Electrical and Electronics Engineering (with distinction) from Federal Polytechnic Offa, Nigeria in 2010. He is currently serving in the Department of Mechatronics Engineering, Federal University Technology Minna, Nigeria.

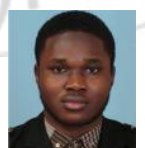

Abdulmuizz Ohiare ABDULMALIK received M. Eng Electromechanical Systems Automation and Electric Drive from Poltava National Yuriy Kondratuk University, Ukraine in 2015. He also received B. Eng Electrical Engineering and Technologies from Volodymr Dahl East Ukraine National University, Ukraine in 2014. He is currently serving in the Department of Mechatronics Engineering, Federal University Technology Minna, Nigeria.

Habeeb Abiodun TIAMIU received Higher National Diploma (HND) and Ordinary National Diploma (OND) Mechanical Engineering from the Federal Polytechnic Offa, Nigeria in 2010 and 2014 respectively. He is currently working at the Halex Autosolution, Owobi Ota, Ogun State, Nigeria. 